\title{
Israel, the Palestinian Factions, and the Cycle Of Violence
}

\author{
David A. Jaeger \\ College of William and Mary and IZA \\ M. Daniele Paserman \\ Hebrew University, IZA, and CEPR
}

College of William and Mary

Department of Economics

Working Paper Number 23

December 2005

We thank Yaron Aronshtam, Tatiana Slobodnitsky, Tamar Roth, Eran Ben-Ari, and Lisa Andruyszyn for outstanding research assistance, Suhair Abdi and Yael Handelsman of B'Tselem for discussions about data as well as providing data on suicide bombings, Maj. Gen. (ret.) Netzach Mashiach for providing us the data on the separation barrier. 
COLLEGE OF WILLIAM AND MARY

DEPARTMENT OF ECONOMICS

WORKING PAPER \# 23

December 2005

\title{
Israel, the Palestinian Factions, and the Cycle of Violence
}

\begin{abstract}
In this study we extend our previous work to examine the dynamic relationship between violence committed by Palestinian factions and that committed by Israel during the Second Intifada. We find a statistically significant relationship between Israeli fatalities claimed by groups associated with the ruling political party, Fatah, and subsequent Palestinian fatalities. We do not find a similar relationship for Israeli fatalities claimed by Hamas, Palestinian Islamic Jihad, and other Palestinian factions. We conjecture that these differences are due to the different positions of the factions vis-a-vis bargaining over a two-state solution to the conflict as well as the organizational structures of the factions.
\end{abstract}

JEL Codes: C32, D71, D74, H56

Keywords: Intifada, terrorism, conflict resolution, bargaining, violence.

David A. Jaeger

Department of Economics

College of William and Mary

P.O. Box 8795

Williamsburg, VA 23187-8795

djaeger@wm.edu
M. Daniele Paserman

The Hebrew University of Jerusalem

Mount Scopus

Jerusalem, 91905

Israel

dpaserma@shum.huji.ac.il 
Since September 2000, Israel and the Palestinians have been engaged in a deadly conflict, commonly known as the Second (or "al-Aqsa") Intifada, which has claimed more than 1,000 Israeli and 3,300 Palestinian lives. In previous work (David A. Jaeger and M. Daniele Paserman, 2005, henceforth JP), we showed that the conventional wisdom that the two sides are locked in an endless cycle of violence, where actions by one side are always followed by retaliations from the other, followed by counter-retaliations ad infinitum, does not appropriately capture the dynamics of the conflict. Rather, Israel responds in a predictable and systematic way to Palestinian violence, while the Palestinians' actions do not seem to be related to past levels of Israeli violence, either through revenge, deterrence or incapacitation. In that analysis, we treated the Palestinians as a unified entity, but to understand the dynamics of the relationship better, it may be necessary to take into account that a number of different Palestinian factions engage in violence against Israel, and that these factions may have different organizational structures and long-term objectives. Moreover, Israel may have incentives to react differentially to violence by the various Palestinian factions.

The three main Palestinian factions involved in violence against Israel are Fatah (and the various groups affiliated with it, in particular the Al-Aqsa Martyr Brigades), Hamas, and the Palestinian Islamic Jihad. Fatah was founded by Yasir Arafat in 1959, and from 1969 it has been the controlling group of the Palestinian national movement, first in the Palestinian Liberation Organization (PLO), and subsequently in the Palestinian National Authority (PA), after it was established in 1993 following the Oslo Peace Accords. As the majority party, Fatah has been the primary negotiator with the Israeli government. It has adopted the two-state approach to the solution of the conflict, agreeing in principle to a partition of mandatory Palestine between a 
Jewish and a Palestinian state, although the issues of Jerusalem, the final borders of the Palestinian state, and the status of refugees have been postponed to final status negotiations.

Unlike Fatah, Hamas and Palestinian Islamic Jihad (PIJ) do not entertain the possibility of a two-state solution. Hamas has expressly called for the destruction of Israel and the establishment of an Islamist state in all of mandatory Palestine, a goal shared by PIJ. Hamas has stronger support in the Gaza Strip, where it provides some social services for the poor. Up until 2005, Hamas had shunned politics at the "national" level, focusing instead on involvement in local municipal councils. PIJ, in contrast, is uninvolved in social or political issues. Both groups have been classified as terrorist organizations by the United States and the European Union. ${ }^{1}$

Several previous papers have modeled the strategic interplay between moderate and radical groups in the Palestinian-Israeli conflict or other armed struggles between insurgents and a central government. These papers have different predictions for the timing and magnitude of violent actions and for the identity of the groups carrying out the attacks. Andrew Kydd and Barbara F. Walter (2002) argue that extremist violence is not indiscriminate or irrational, but rather is timed to coincide with major developments in a peace process, with the aim of sabotaging diplomatic efforts. In contrast, Mia M. Bloom (2004) emphasizes the role of political competition between the different Palestinian factions, claiming that they use suicide bombings as a means to boost prestige and popularity. Robert A. Pape (2003) and Claude Berrebi and Esteban Klor (2005) argue instead that Palestinian groups use violence to extract territorial concessions from Israel. In Berrebi and Klor's model, the radical group (Hamas) always chooses to exercise violence, while the moderate Palestinian Authority, whose goal is to achieve emancipation for the occupied territories, can choose either to fight the radical group and attempt

\footnotetext{
${ }^{1}$ A variety of smaller groups, such as the Marxist Popular Front for the Liberation of Palestine and the Democratic Front for the Liberation of Palestine, has also claimed responsibility for a small number of Israeli fatalities during the course of the second Intifada.
} 
to thwart terrorist attacks, or to allow these attacks and thus increase the expected level of terrorist activity. A variety of other studies examine antiterrorism policies and their effectiveness (Walter Enders and Todd Sandler, 1993; Bryan Brophy-Baermann and John A. C. Conybeare, 1994; and Asaf Zussman and Noam Zussman, forthcoming). None of these studies, however, addresses the possibility that Israel's actions may also be strategic, and that it may choose to act differently in response to violence by different factions. Here we directly and empirically explore this possibility, and test whether the magnitude and the targets of Israel's response to Palestinian violence depends on the identity of the factions claiming responsibility for the attacks.

\section{Data and Descriptive Statistics}

We rely on two sources for data: the web site of B'tselem (http://www.btselem.org), an Israeli human rights organization, and the database on incidents and casualties in the Second Intifada prepared by the Institute for Counter Terrorism (ICT) at the Interdisciplinary Center in Herzliya, Israel (http://www.ict.org.il).

In the statistics section of its Hebrew web site, B'tselem records in detail every fatality on both sides of the conflict during the second Intifada. ${ }^{2}$ The data include the date and the circumstances of the fatal wounding, the name, age, sex and locality of residence of the victim. For Israelis, the site records whether the fatality was a civilian or a member of the security forces; for Palestinians, the site records whether the fatality was involved in combat or not, and whether it belonged to the Israeli Army's "wanted" list. Among the advantages of this data set are its comprehensiveness and the symmetrical treatment of both sides of the conflict. More

\footnotetext{
${ }^{2}$ Suicide bombers are excluded from these data, as are Arab citizens of Israel killed by the Israeli security forces or by Israeli civilians and Israelis killed by Arab citizens of Israel or by foreign nationals.
} 
importantly, the information published by B'tselem is widely thought to be accurate and reliable. $^{3}$

The B'tselem data unfortunately lack information on the militant group affiliation of the Palestinian fatalities and do not report the Palestinian group that claims responsibility for Israeli fatalities. To overcome these shortcomings, we cross-validated the B'tselem data with data from the ICT. The ICT maintains a database with information on all incidents and casualties during the course of the Second Intifada. The ICT database records all of the variables collected by B'tselem as well as the Palestinian organization involved in the incident, i.e. the organizational affiliation of the victim for Palestinian combatants, and the group claiming responsibility for Israeli fatalities. We focused on the period between the outbreak of the Second Intifada (September 2000) until the end of August 2004, and tried to match manually every record in the B'tselem data to a corresponding record in the ICT data, using names, dates, and all other available information that could help identify the individual. ${ }^{4}$

In Table 1, we present the distribution of Palestinian fatalities by combatant status and organizational affiliation. ${ }^{5}$ Roughly 45 percent of all Palestinian fatalities were combatants, 42 percent were noncombatants, and the combatant status of the remainder was unknown. We were able to identify the organizational affiliation of more than 60 percent of combatants: of these,

\footnotetext{
${ }^{3}$ From the B'tselem website: "B'Tselem has attained a prominent place among human rights organizations. In December, 1989 it received the Carter-Menil Award for Human Rights. Its reports have gained B'Tselem a reputation for accuracy, and the Israeli authorities relate to them seriously. B'Tselem ensures the reliability of information it publishes by conducting its own fieldwork and research, whose results are thoroughly cross-checked with relevant documents, official government sources, and information from other sources, among them Israeli, Palestinian, and other human rights organizations."

${ }^{4}$ The match rate was more than 99 percent among Israeli fatalities, and more than 72 percent among Palestinian fatalities.

${ }^{5}$ A Palestinian was defined as a combatant if he was listed as a combatant in the ICT data, or if his combatant status was unknown in the ICT and he was listed as a combatant in the B'tselem data. Similarly, a Palestinian was defined as non-combatant if he was listed as a noncombatant in the ICT data, or if his combatant status was unknown in the ICT data and he was listed as a noncombatant in the B'tselem data. Finally, an individual's combatant status was recorded as unknown if information on combatant status was missing in both the ICT and the B'tselem data.
} 
roughly half belonged to one of the groups affiliated with Fatah, a third belonged to Hamas, and about a sixth belonged to PIJ.

We present the distribution of Israeli fatalities, by the faction claiming responsibility for the fatal attack in Table 2. The group claiming the single largest number of Israeli fatalities is Hamas (42 percent), followed by Fatah (34 percent), and PIJ (13 percent). Roughly two and a half percent of Israeli fatalities have been claimed by smaller groups, while 8 percent are not claimed by any group. Interestingly, the number of days with fatalities claimed by Fatah is more than double the number of days with fatalities claimed by Hamas, testifying to the more deadly methods or the efficiency of Hamas: the average number of Hamas-claimed fatalities per day is roughly 6.6 , compared to 2.33 for Fatah, and 3.6 for PIJ. ${ }^{6}$

\section{Reaction Functions}

To estimate Israel's reactions to Palestinian violence, we employ a simple econometric framework similar to that used in JP. We focus here on the incidence of reaction as a function of the past actions of Israel and the Palestinian factions. As an example, consider the reaction function we estimate for Israel against Fatah:

$$
\begin{aligned}
F_{t}= & \alpha+\beta_{1}^{F} I_{(t-1 \text { to } t-7)}^{F}+\beta_{2}^{F} I_{(t-8 \text { to } t-14)}^{F}+\beta_{1}^{H} I_{(t-1 \text { to } t-7)}^{H}+\beta_{2}^{H} I_{(t-8 \text { to } t-14)}^{H}+ \\
& \beta_{1}^{P I J} I_{(t-1 \text { to } t-7)}^{P I J}+\beta_{2}^{P I J} I_{(t-8 \text { to } t-14)}^{P I J}+\beta_{1}^{\text {OTH }} I_{(t-1 \text { to } t-7)}^{\text {OTH }}+\beta_{2}^{\text {OTH }} I_{(t-8 \text { to } t-14)}^{\text {OTH }}+ \\
& \gamma_{1} P_{(t-1 \text { to } t-7)}+\gamma_{2} P_{(t-8 \text { to } t-14)}+\mathbf{X}_{t} \delta+\varepsilon_{t}
\end{aligned}
$$

where $F_{t}$ is the incidence of fatalities of combatants from Fatah on day $t, I_{(t-1 \text { to } t-7)}^{F}$ is the number of days with Israeli fatalities claimed by Fatah in the first seven-day period prior to day $t$, and $I_{(t-8 \text { to } t-14)}^{F}$ is the number of days with Israeli fatalities claimed by Fatah in the second seven-day

\footnotetext{
${ }^{6}$ Eli Berman and David D. Laitin (2005) have also noted the relative efficiency of Hamas in carrying out suicide bombings.
} 
period prior to day $t$. The other variables are defined similarly, and represent the lagged number of days with Israeli fatalities claimed by Hamas, Palestinian Islamic Jihad, and other combatant groups. To parsimoniously control for serial correlation in Israel's actions, we also include variables for the lagged number of days with any Palestinian fatalities, $P_{(t-1}$ to $\left.t-8\right)$ and $P_{(t-1}$ to $\left.t-8\right)$. Lastly, the vector $\mathbf{X}_{t}$ is a set of day-of-week and period-of-conflict variables as well as a variable measuring the length of the separation barrier between the West Bank and Israel. We define these variables and explore a variety of functional form issues (to which the results are robust) in JP.

We define Israel's reaction function against the other factions similarly, with only the dependent variable changing, and also include regressions for Palestinian fatalities that are characterized as non-combatants and whose combatant status is unknown. The regressions are estimated as linear probability models and because the error terms in the different reaction functions are likely to be correlated, we treat them as a set of seemingly unrelated regressions. The estimated standard errors are also heteroskedasticity-consistent.

We present the results of estimating the Israeli reaction functions against the different factions in Table 3. For comparison purposes, in the last column we present results using the incidence of all Palestinian fatalities as the dependent variable. In addition to the coefficient estimates, in each column we present $\chi^{2}$ statistics for the joint statistical significance of all of the faction coefficients as well as only the "own" coefficients of the faction under examination. If the regressors are orthogonal to the error term in this regression, we can interpret these as testing whether Palestinian violence (in toto or by the individual factions, respectively) causes an Israeli response. In JP, we explored at length the issue of whether we can attach a causal interpretation 
to these tests in similar regressions involving the overall level of fatalities on both sides and concluded that there is little reason to believe that a causal interpretation is inappropriate.

In each column we also present $\chi^{2}$ for the test of the hypothesis that all of the coefficients on the faction variables are equal. For each row, we present $\chi^{2}$ statistics for the test that all of the coefficients for a particular faction are equal across the different reaction functions. Finally, in the lower right hand corner of the table, we present the $\chi^{2}$ statistic for the test that all of the coefficients along the diagonal of the table are equal, that is, that Israel reacts in the same way against each of the factions when they claim an Israeli fatality.

We find that Israel responds differentially to violence committed by the different factions. It reacts in a significant and positive way to fatalities claimed by Fatah, but not to those committed by the other factions. Violence by Fatah appears to affect Israeli's response to the other groups as well, significantly increasing the incidence of fatalities for all groups except PIJ, which (in the second lag) appears to be negatively related to Fatah violence. The incidence of noncombatant fatalities is also positively affected by past Fatah violence, but not by past violence by Hamas and Palestinian Islamic Jihad. The results in the last column, in which we use the incidence of any Palestinian fatality (regardless of faction) as the dependent variable, reinforce our conclusion that Israel reacts primarily to violence by Fatah but not violence against Hamas. The estimated coefficient for Israel's reaction against Palestinian Islamic Jihad is also large, but not statistically significant.

We now turn to the analysis of the various tests for equality of coefficients across rows and columns, focusing in particular on the two most important groups, Fatah and Hamas. The row tests show that Israel responds differentially against the different factions when Fatah commits violence, but it is not possible to reject the null that Israel's response to Hamas violence 
is uniform across all factions. The column tests show that all the faction coefficients are jointly statistically significant in the reaction function against Fatah, but one cannot reject the null that all coefficients are equal to zero in the reaction function against Hamas. In other words, violence against Fatah can be predicted by past levels of Palestinian violence, but violence against Hamas cannot. Only for Fatah do we find a statistically significant relationship between its "own" violence and Israel's response against it. Finally, the test of equality of column coefficients shows that Israel's reaction against Fatah varies depending on which faction was responsible for past Israeli fatalities, while we cannot reject that Israel's reaction against Hamas is independent of the faction claiming responsibility for the attacks.

We have estimated similar models examining the reactions of the Palestinian factions to Israeli violence. As for the general results presented in JP, we find little evidence that there is any relationship between Israeli violence and a response by any of the factions. These results are not presented here due to space constraints and are available from the authors by request.

\section{Discussion}

Why does Israel react differently to the various factions? We conjecture that Israel's incentives to react may differ because of the contrasting long-term objectives of the Palestinian factions as well as their different organizational structures. The relatively moderate Fatah has endorsed the two-state approach to the solution of the conflict, has been the primary negotiator with Israel over that solution, and is likely to play a major role in representing the Palestinians at any future negotiations. Whether it engages in violence to extract territorial concessions or to boost its prestige and popularity among the Palestinian public, its choices on the timing and magnitude of the attacks are strategic, and there is likely to be a scope for deterrent actions by 
Israel. Israel has the organization and technical means to respond quickly when Fatah claims responsibility for an attack, and it also has an incentive to respond directly and in a timely way, to make obvious that it is willing to use its military strength and to reduce any net benefit of Fatah violence. In addition, the prospect of future negotiations with Fatah, Israel's primary bargaining partner, may also dictate the timing of Israel's response. Because bargaining strength on either side is a function of past violence, each side has an incentive to have the "last word" prior to negotiations.

On the other hand, it is less clear what incentives Israel has to react systematically to violence by Hamas and PIJ. These groups are explicitly committed to the destruction of the State of Israel, and are opposed to any negotiated settlement on the basis of territorial concessions. Berrebi and Klor (2005) explicitly assume that the radical groups' behavior is non-strategic and that they always pursue the violent option. If this is so, the timing of Israel's response against Hamas and PIJ would not necessarily be related to previous actions, even though Israel clearly has incentives to try to incapacitate these groups. ${ }^{7}$

The difference in Israel's response may also be due to the different organizational and military structure of the different armed groups. The Al-Aqsa Martyr Brigades (AAMB) and the Tanzim (the primary armed groups affiliated with Fatah) have a fairly decentralized structure. In its section on the profiles of terrorist organizations, the ICT website describes the AAMB as "a loose network of cells in the main West Bank cities." An attack by the AAMB reveals information about the capabilities and (perhaps) the location of a cell. Because of the decentralized command structure of the AAMB, removing a cell may lead to a longer-term

\footnotetext{
${ }^{7}$ We would also be less likely to observe a direct connection between violence by radical groups and an Israeli response if the radicals act primarily in order to derail the peace process, as suggested by Kydd and Walter (2002), since then Israel itself would try to refrain from violence in order to keep the peace process on track. In any case, this model for radical violence is not very relevant for the period under examination, as all negotiations on substantive issues were stalled.
} 
reduction in violence. In contrast, Hamas, in particular, is centrally commanded and well organized. Removing a cell of "foot soldiers" may only lead to the quick replacement of those foot soldiers; Israel has greater incentive to target the leadership of Hamas. An individual attack by Hamas, however, may not reveal any new information about the capabilities or location of that leadership. Because of the large sacrifices it demands of its members, Hamas also may be better able to screen its operatives and ensure loyalty (Berman and Laitin, 2005), thus making it more difficult to infiltrate the group and extract information on the planners of the attack. Therefore, Israel's response against Hamas is less likely to be temporally linked to individual attacks claimed by Hamas, and will depend more on intelligence gathering and the opportunity to strike its leaders.

These results make clear that Israel's response to Palestinian violence depends on the group that committed that violence, suggesting that Israel's response is in part based on strategic considerations vis-à-vis the Palestinian factions. Understanding this complex relationship between the Palestinian factions and Israel is the focus of our ongoing research. 


\section{REFERENCES}

Berman, Eli and Laitin, David D. "Hard Targets: Theory and Evidence on Suicide Attacks." NBER (Cambridge, MA) Working Paper 11740, November 2005.

Berrebi, Claude and Klor, Esteban F. "On Terrorism and Electoral Outcomes: Theory and Evidence from the Israeli-Palestinian Conflict." Mimeo, Hebrew University, November 2005.

Bloom, Mia M. "Palestinian Suicide Bombing: Public Support, Market Share and Outbidding." Political Sciences Quarterly, 119:1 (Spring 2004), 61-88.

Brophy-Baermann, Bryan and Conybeare, John A.C. "Retaliating Against Terrorism: Rational Expectations and the Optimality of Rules versus Discretion," American Journal of Political Science 38:1 (February 1994), 196-210.

Enders, Walter and Sandler, Todd. "A VAR-Intervention Analysis of Anti-Terrorism Policies,” American Political Science Review 87 (December 1993), 829-44.

Jaeger, David A. and Paserman, M. Daniele. "The Cycle of Violence? An Empirical Analysis of Fatalities in the Palestinian-Israeli Conflict." IZA (Bonn, Germany), Discussion Paper 1808 , October 2005.

Kydd, Andrew and Walter, Barbara F. "Sabotaging the Peace: The Politics of Extremist Violence," International Organization 56:2 (Spring 2002), 263-296.

Pape, Robert A. "The Strategic Logic of Suicide Terrorism," American Political Science Review 97:3 (August 2003), 1-19.

Zussman, Asaf and Zussman, Noam. "Assassinations: Evaluating the Effectiveness of a Counterterrorism Policy Using Stock Market Data," Journal of Economic Perspectives, forthcoming. 
Table 1

Combatant Status and Organizational Affiliation of Palestinian Fatalities

\begin{tabular}{lccc}
\hline & & \multicolumn{2}{c}{ Share of } \\
\cline { 3 - 5 } Status, Faction & $\begin{array}{c}\text { Number of } \\
\text { Fatalities }\end{array}$ & $\begin{array}{c}\text { Total } \\
\text { Fatalities }\end{array}$ & $\begin{array}{c}\text { Combatant } \\
\text { Fatalities }\end{array}$ \\
\hline Combatants & 1,272 & .447 & \\
$\quad$ Fatah & 388 & .136 & .305 \\
$\quad$ Hamas & 294 & .103 & .231 \\
$\quad$ Palestinian Islamic Jihad & 112 & .039 & .088 \\
$\quad$ Other or unknown & 478 & .168 & .376 \\
Non-combatants & 1,197 & .420 & \\
Unknown & 379 & .133 & \\
Total & 2,848 & & \\
\hline
\end{tabular}

Source: Authors' tabulations using data from B'Tselem and ICT, from 29

September 2000 to 31 August 2004. 
Table 2

Distribution of Israeli Fatalities by

Palestinian Faction Claiming Responsibility

\begin{tabular}{lcccc}
\hline & Share & $\begin{array}{c}\text { Average } \\
\text { Number of } \\
\text { Faction }\end{array}$ & $\begin{array}{c}\text { fays with } \\
\text { fatalities }\end{array}$ & $\begin{array}{c}\text { fatalities on } \\
\text { days with } \\
\text { fatalities }\end{array}$ \\
\hline Fatah & 322 & .336 & 138 & 2.33 \\
Hamas & 402 & .420 & 61 & 6.59 \\
Islamic Jihad & 130 & .136 & 36 & 3.61 \\
Other & 25 & .026 & 12 & 2.08 \\
Not claimed & 78 & .082 & 63 & 1.24 \\
Total & 957 & & 280 & 3.42 \\
\hline
\end{tabular}

Source: See note to Table 1. 
Table 3

Israeli Reaction Functions

(absolute value of heteroskedasticity-consistent $z$-ratios in brackets, $p$-values in parentheses)

\begin{tabular}{|c|c|c|c|c|c|c|c|c|}
\hline \multirow[b]{2}{*}{$\begin{array}{l}\text { Number of Days with } \\
\text { Israeli Fatalities } \\
\text { claimed by: }\end{array}$} & \multicolumn{6}{|c|}{ Affiliation of Palestinian Fatality } & \multirow{2}{*}{$\begin{array}{l}\text { Row test } \\
\chi^{2} \text { test, } \\
\text { all coefs. } \\
\text { equal }\end{array}$} & \multirow[b]{2}{*}{ All } \\
\hline & Fatah & Hamas & $\begin{array}{c}\text { Pal. } \\
\text { Islamic } \\
\text { Jihad } \\
\end{array}$ & Other & $\begin{array}{c}\text { Non } \\
\text { com- } \\
\text { batant }\end{array}$ & $\begin{array}{c}\text { Un- } \\
\text { known }\end{array}$ & & \\
\hline \multicolumn{9}{|l|}{ Fatah } \\
\hline$t-1$ to $t-7$ & $\begin{array}{c}0.0292 \\
{[2.31]}\end{array}$ & $\begin{array}{c}-0.0016 \\
{[0.16]}\end{array}$ & $\begin{array}{l}0.0095 \\
{[1.30]}\end{array}$ & $\begin{array}{l}0.0309 \\
{[2.43]}\end{array}$ & $\begin{array}{c}0.0446 \\
{[3.01]}\end{array}$ & $\begin{array}{l}0.0393 \\
{[3.48]}\end{array}$ & $\begin{array}{c}40.041 \\
(<0.001)\end{array}$ & $\begin{array}{l}0.0383 \\
{[2.79]}\end{array}$ \\
\hline$t-8$ to $t-14$ & $\begin{array}{l}0.0197 \\
{[1.55]}\end{array}$ & $\begin{array}{l}0.0224 \\
{[2.07]}\end{array}$ & $\begin{array}{r}-0.0199 \\
{[3.02]}\end{array}$ & $\begin{array}{l}0.0376 \\
{[2.86]}\end{array}$ & $\begin{array}{l}0.0171 \\
{[1.09]}\end{array}$ & $\begin{array}{l}0.0073 \\
{[0.65]}\end{array}$ & & $\begin{array}{l}0.0280 \\
{[1.91]}\end{array}$ \\
\hline \multicolumn{9}{|l|}{ Hamas } \\
\hline$t-1$ to $t-7$ & $\begin{array}{c}0.0151 \\
{[0.77]}\end{array}$ & $\begin{array}{r}-0.0143 \\
{[0.90]}\end{array}$ & $\begin{array}{l}0.0075 \\
{[0.56]}\end{array}$ & $\begin{array}{c}0.0135 \\
{[0.62]}\end{array}$ & $\begin{array}{c}0.0202 \\
{[0.82]}\end{array}$ & $\begin{array}{c}-0.0088 \\
{[0.50]}\end{array}$ & $\begin{array}{l}12.471 \\
(0.255)\end{array}$ & $\begin{array}{r}-0.0000 \\
{[0.00]}\end{array}$ \\
\hline$t-8$ to $t-14$ & $\begin{array}{r}-0.0430 \\
{[2.35]}\end{array}$ & $\begin{array}{c}0.0194 \\
{[1.03]}\end{array}$ & $\begin{array}{l}0.0050 \\
{[0.42]}\end{array}$ & $\begin{array}{r}-0.0155 \\
{[0.73]}\end{array}$ & $\begin{array}{l}0.0221 \\
{[0.88]}\end{array}$ & $\begin{array}{r}-0.0080 \\
{[0.50]}\end{array}$ & & $\begin{array}{l}0.0145 \\
{[0.60]}\end{array}$ \\
\hline \multicolumn{9}{|l|}{ Palestinan Islamic Jihad } \\
\hline$t-1$ to $t-7$ & $\begin{array}{r}-0.0431 \\
{[1.78]}\end{array}$ & $\begin{array}{r}-0.0203 \\
{[0.94]}\end{array}$ & $\begin{array}{c}0.0244 \\
{[1.47]}\end{array}$ & $\begin{array}{l}0.0013 \\
{[0.05]}\end{array}$ & $\begin{array}{l}0.0483 \\
{[1.42]}\end{array}$ & $\begin{array}{l}0.0619 \\
{[2.41]}\end{array}$ & $\begin{array}{l}21.294 \\
(0.019)\end{array}$ & $\begin{array}{l}0.0430 \\
{[1.35]}\end{array}$ \\
\hline$t-8$ to $t-14$ & $\begin{array}{l}0.0378 \\
{[1.40]}\end{array}$ & $\begin{array}{r}-0.0005 \\
{[0.02]}\end{array}$ & $\begin{array}{r}-0.0142 \\
{[0.98]}\end{array}$ & $\begin{array}{l}0.0042 \\
{[0.15]}\end{array}$ & $\begin{array}{c}0.0506 \\
{[1.51]}\end{array}$ & $\begin{array}{l}0.0575 \\
{[2.42]}\end{array}$ & & $\begin{array}{l}0.0476 \\
{[1.52]}\end{array}$ \\
\hline \multicolumn{9}{|l|}{ Other } \\
\hline$t-1$ to $t-7$ & $\begin{array}{l}0.0370 \\
{[2.18]}\end{array}$ & $\begin{array}{l}0.0192 \\
{[1.35]}\end{array}$ & $\begin{array}{r}-0.0174 \\
{[1.85]}\end{array}$ & $\begin{array}{l}0.0240 \\
{[1.34]}\end{array}$ & $\begin{array}{l}0.0538 \\
{[2.53]}\end{array}$ & $\begin{array}{l}0.0449 \\
{[3.15]}\end{array}$ & $\begin{array}{l}23.505 \\
(0.009)\end{array}$ & $\begin{array}{l}0.0357 \\
{[1.82]}\end{array}$ \\
\hline$t-8$ to $t-14$ & $\begin{array}{l}0.0032 \\
{[0.20]}\end{array}$ & $\begin{array}{r}-0.0072 \\
{[0.51]}\end{array}$ & $\begin{array}{l}0.0007 \\
{[0.08]}\end{array}$ & $\begin{array}{l}0.0100 \\
{[0.58]}\end{array}$ & $\begin{array}{l}0.0009 \\
{[0.04]}\end{array}$ & $\begin{array}{r}-0.0228 \\
{[1.83]}\end{array}$ & & $\begin{array}{l}0.0026 \\
{[0.12]}\end{array}$ \\
\hline \multicolumn{9}{|l|}{ Column Tests } \\
\hline $\begin{array}{l}\chi^{2} \text { test, } \\
\text { All factions }=0\end{array}$ & $\begin{array}{l}26.376 \\
(0.001)\end{array}$ & $\begin{array}{l}8.148 \\
(0.419)\end{array}$ & $\begin{array}{l}14.015 \\
(0.081)\end{array}$ & $\begin{array}{l}20.025 \\
(0.010)\end{array}$ & $\begin{array}{l}31.779 \\
(<.001)\end{array}$ & $\begin{array}{l}35.390 \\
(<.001)\end{array}$ & & \\
\hline $\begin{array}{l}\chi^{2} \text { test, } \\
\text { Own faction }=0\end{array}$ & $\begin{array}{c}8.659 \\
(0.013)\end{array}$ & $\begin{array}{l}1.987 \\
(0.370)\end{array}$ & $\begin{array}{l}2.935 \\
(0.231)\end{array}$ & $\begin{array}{c}2.273 \\
(0.321)\end{array}$ & & & & \\
\hline $\begin{array}{l}\chi^{2} \text { test } \\
\text { All factions equal }\end{array}$ & $\begin{array}{l}17.967 \\
(0.006)\end{array}$ & $\begin{array}{c}5.786 \\
(0.448)\end{array}$ & $\begin{array}{l}9.757 \\
(0.135)\end{array}$ & $\begin{array}{c}5.677 \\
(0.460)\end{array}$ & $\begin{array}{c}2.764 \\
(0.838)\end{array}$ & $\begin{array}{l}17.132 \\
(0.009)\end{array}$ & & \\
\hline $\begin{array}{l}\text { "Diagonal" Tests } \\
\text { All "own" coeffs. equal }\end{array}$ & & & & & & & $\begin{array}{c}8.988 \\
(0.174)\end{array}$ & \\
\hline
\end{tabular}

Source: see note to Table 1.

Note: Dependent variables are daily indicators of any fatalities of faction members. Independent variables are number of days with any Israel deaths claimed by faction in periods $t-1$ to $t-7$ and $t-8$ to $t-14$. Regressions also include the length of the separation barrier and lagged day-of-week and phase-of-conflict dummy variables as covariates. Variance-covariance matrix of estimates is heteroskedasticity-consistent and takes into account correlations in the error terms across equations. 